\title{
Reinvestigation of the Phase Equilibria in the La_2O_3-P_2O_5 System
}

$\operatorname{AUTHOR}(S)$ :

Hatada, Naoyuki; Nagai, Takashi; Nose, Yoshitaro; Uda, Tetsuya

\section{CITATION:}

Hatada, Naoyuki ...[et al]. Reinvestigation of the Phase Equilibria in the La_2O_3-P_2O_5 System. Journal of Phase Equilibria and Diffusion 2013, 34(3): 196-201

\section{ISSUE DATE:}

2013-06

URL:

http://hdl.handle.net/2433/191003

\section{RIGHT:}

(c) 2013 ASM International. This paper was published in Journal of Phase Equilibria and Diffusion, Vol.34, Issue 3, pp. 196-201 and is made available as an electronic reprint with the permission of ASM International. One print or electronic copy may be made for personal use only. Systematic or multiple reproduction, distribution to multiple locations via electronic or other means, duplications of any material in this paper for a fee or for commercial purposes, or modification of the content of this paper are prohibited. 


\section{Reinvestigation of the Phase Equilibria in the $\mathrm{La}_{2} \mathrm{O}_{3}-\mathrm{P}_{2} \mathrm{O}_{5}$ System}

Naoyuki Hatada, Takashi Nagai, Yoshitaro Nose, and Tetsuya Uda

(Submitted October 9, 2012; in revised form December 28, 2012; published online February 12, 2013)

The phase equilibria between the solid phases in the $\mathrm{La}_{2} \mathrm{O}_{3}-\mathrm{P}_{2} \mathrm{O}_{5}$ system were reinvestigated with solid state reaction method. The existence of $\mathrm{La}_{3} \mathrm{PO}_{7}, \mathrm{La}_{7} \mathrm{P}_{3} \mathrm{O}_{18}, \mathrm{LaPO}_{4}$, and $\mathrm{LaP}_{3} \mathrm{O}_{9}$ was confirmed. $\mathrm{La}_{7} \mathrm{P}_{3} \mathrm{O}_{18}$ can form only at $\sim 1200{ }^{\circ} \mathrm{C}$ or higher possibly due to kinetic reasons, but it is stable at lower temperatures. On the other hand, three intermediate compounds proposed to exist, $\mathrm{La}_{5} \mathrm{PO}_{10}, \mathrm{La}_{4}\left(\mathrm{P}_{2} \mathrm{O}_{7}\right)_{3}$, and $\mathrm{La}_{2} \mathrm{P}_{4} \mathrm{O}_{13}$ were not obtained in this study. Based on the literature, $\mathrm{La}_{4}\left(\mathrm{P}_{2} \mathrm{O}_{7}\right)_{3}$ and $\mathrm{La}_{2} \mathrm{P}_{4} \mathrm{O}_{13}$ are considered to be metastable phases, although thermodynamic evidence is still required.

Keywords lanthanum phosphate, phase diagram, solid state reaction

\section{Introduction}

Various phosphates in the $\mathrm{La}_{2} \mathrm{O}_{3}-\mathrm{P}_{2} \mathrm{O}_{5}$ system have been studied as proton conductors, ${ }^{[1-4]}$ laser and luminescent materials, ${ }^{[5-8]}$ phosphorus diffusion sources for semiconductors, ${ }^{[9-11]}$ debond materials in oxide composites, ${ }^{[12]}$ coating materials, ${ }^{[13]}$ and radioactive waste forms. ${ }^{[14-16]}$ Two temperature-composition phase diagrams have been reported for the $\mathrm{La}_{2} \mathrm{O}_{3}-\mathrm{P}_{2} \mathrm{O}_{5}$ system in the literature. ${ }^{[17,18]} \mathrm{In}$ addition, the phase equilibria in the $\mathrm{La}_{2} \mathrm{O}_{3}-\mathrm{P}_{2} \mathrm{O}_{5}$ system have been studied as a part of ternary systems. ${ }^{[19-22]}$ However, there are several inconsistencies among these phase diagrams. Table 1 summarizes the intermediate compounds reported to exist in each phase diagram. As indicated in the table, the existences of $\mathrm{La}_{3} \mathrm{PO}_{7}, \mathrm{LaPO}_{4}$, $\mathrm{LaP}_{3} \mathrm{O}_{9}$, and $\mathrm{LaP}_{5} \mathrm{O}_{14}$ have been well established. These compounds were also confirmed to be thermodynamically stable compounds in the $\mathrm{La}_{2} \mathrm{O}_{3}-\mathrm{P}_{2} \mathrm{O}_{5}$ system by firstprinciples calculations. ${ }^{[23]}$ In contrast, the existence of $\mathrm{La}_{5} \mathrm{PO}_{10}, \mathrm{La}_{7} \mathrm{P}_{3} \mathrm{O}_{18}, \mathrm{La}_{4}\left(\mathrm{P}_{2} \mathrm{O}_{7}\right)_{3}$, and $\mathrm{La}_{2} \mathrm{P}_{4} \mathrm{O}_{13}$ has been controversial, and their crystal structures and thermodynamic properties are still unknown. To construct the reliable

Naoyuki Hatada, Department of Materials Science and Engineering, Kyoto University, Yoshida Honmachi, Sakyo-ku, Kyoto 606-8501, Japan; and Environmental Technology Research Division, INAMORI Frontier Research Center, Kyushu University, 744 Motooka, Nishi-ku, Fukuoka 819-0395, Japan; Takashi Nagai, Institute of Industrial Science, The University of Tokyo, 4-6-1 Komaba, Meguro-Ku, Tokyo 153-8505, Japan; and Department of Mechanical Science and Engineering, Faculty of Engineering, Chiba Institute of Technology,17-1, Tsudanuma 2-chome, Narashino, Chiba 275-0016, Japan; and Yoshitaro Nose and Tetsuya Uda, Department of Materials Science and Engineering, Kyoto University, Yoshida Honmachi, Sakyo-ku, Kyoto 606-8501, Japan. Contact e-mail: materials_process@ aqua.mtl.kyoto-u.ac.jp. phase diagram for the $\mathrm{La}_{2} \mathrm{O}_{3}-\mathrm{P}_{2} \mathrm{O}_{5}$ system, the existence and stability of these compounds must be verified. In this work, the phase equilibria between the solid phases in the $\mathrm{La}_{2} \mathrm{O}_{3}$ $\mathrm{P}_{2} \mathrm{O}_{5}$ system have been reinvestigated with solid state reaction method.

Here, a brief description is given on the compounds whose existence should be confirmed, $\mathrm{La}_{5} \mathrm{PO}_{10}, \mathrm{La}_{7} \mathrm{P}_{3} \mathrm{O}_{18}$, $\mathrm{La}_{4}\left(\mathrm{P}_{2} \mathrm{O}_{7}\right)_{3}$, and $\mathrm{La}_{2} \mathrm{P}_{4} \mathrm{O}_{13}$. Since the $\mathrm{Nd}_{2} \mathrm{O}_{3}-\mathrm{P}_{2} \mathrm{O}_{5}$ system has considerable similarity with the $\mathrm{La}_{2} \mathrm{O}_{3}-\mathrm{P}_{2} \mathrm{O}_{5}$ system in phase equilibrium behaviors, ${ }^{[20,24-27]}$ the information on analogous compounds in the $\mathrm{Nd}_{2} \mathrm{O}_{3}-\mathrm{P}_{2} \mathrm{O}_{5}$ system is also presented below.

\section{1 $\mathrm{La}_{5} \mathrm{PO}_{10}$}

Kropiwnicka and Znamierowska ${ }^{[18,28]}$ obtained $\mathrm{La}_{5} \mathrm{PO}_{10}$ via solid state reaction between $\mathrm{La}_{2} \mathrm{O}_{3}$ and $\mathrm{NH}_{4} \mathrm{H}_{2} \mathrm{PO}_{4}$ at temperatures above $540{ }^{\circ} \mathrm{C}$. By differential thermal analysis, they observed four endothermic effects at 80, 700, 860, and $1180{ }^{\circ} \mathrm{C}$ and they assigned these effects to four polymorphic transitions. They also determined the congruent melting temperature of $\mathrm{La}_{5} \mathrm{PO}_{10}$ to be $1870 \pm 10^{\circ} \mathrm{C}$. However, the formation of $\mathrm{La}_{5} \mathrm{PO}_{10}$ has not been reported by any other group.

\section{$1.2 \mathrm{La}_{7} \mathrm{P}_{3} \mathrm{O}_{18}$}

$\mathrm{La}_{7} \mathrm{P}_{3} \mathrm{O}_{18}$ has been synthesized by several researchers via solid state reactions, solidification of melts, etc. ${ }^{[2,16,17,27,29-31]}$ Serra et al. ${ }^{[30]}$ found that there are low- and high-temperature forms, transforming reversibly at $1650{ }^{\circ} \mathrm{C}$, by hightemperature $\mathrm{x}$-ray diffraction analysis. According to Park and Kreidler, ${ }^{[17]} \mathrm{La}_{7} \mathrm{P}_{3} \mathrm{O}_{18}$ does not have a lower temperature limit of stability. However, $\mathrm{La}_{7} \mathrm{P}_{3} \mathrm{O}_{18}$ is obtainable only at temperatures above $1300{ }^{\circ} \mathrm{C}$ and it has not been synthesized at temperatures below $1200{ }^{\circ} \mathrm{C} .^{[2,20,27,29,31]}$ The coexistence of $\mathrm{La}_{3} \mathrm{PO}_{7}$ and $\mathrm{LaPO}_{4}$ at $1100-1200{ }^{\circ} \mathrm{C}$, instead of forming $\mathrm{La}_{7} \mathrm{P}_{3} \mathrm{O}_{18}$, was also observed by other authors. ${ }^{[32,33]}$ Similarly, it was reported that the neodymium analogue, $\mathrm{Nd}_{7} \mathrm{P}_{3} \mathrm{O}_{18}$, can be formed at above $\sim 1125{ }^{\circ} \mathrm{C}$ by Wong and Kreidler ${ }^{[3]}$ and Tselebrovskaya et al. ${ }^{[20,27]}$ They attributed this to kinetic reasons. 
Table 1 Compounds in the $\mathrm{La}_{2} \mathrm{O}_{3}-\mathrm{P}_{2} \mathrm{O}_{5}$ phase diagrams reported in the literature

\begin{tabular}{|c|c|c|c|c|c|c|c|}
\hline \multirow[b]{2}{*}{ Compound } & \multirow[b]{2}{*}{ Molar ratio, $\mathbf{P} /(\mathbf{L a}+\mathbf{P})$} & \multicolumn{6}{|c|}{ Existence in reported phase diagrams } \\
\hline & & $\begin{array}{c}\text { Ref } 17 \\
\left(700-1500{ }^{\circ} \mathrm{C}\right)\end{array}$ & $\begin{array}{c}\text { Ref } 18 \\
\text { (R.T.-2000 } \\
\left.{ }^{\circ} \mathrm{C}\right)\end{array}$ & $\begin{array}{c}\text { Ref } 19 \\
\left(100-500{ }^{\circ} \mathrm{C}\right)\end{array}$ & $\begin{array}{c}\text { Ref } 20 \\
\left(1300{ }^{\circ} \mathrm{C}\right)\end{array}$ & $\begin{array}{c}\operatorname{Ref} 21 \\
\left(650-1300{ }^{\circ} \mathrm{C}\right)\end{array}$ & $\begin{array}{c}\text { Ref } 22 \\
\left(1200-1400{ }^{\circ} \mathrm{C}\right)\end{array}$ \\
\hline $\mathrm{La}_{5} \mathrm{PO}_{10}$ & 0.167 & No & Yes & $\ldots$ & No & No & No \\
\hline $\mathrm{La}_{3} \mathrm{PO}_{7}$ & 0.25 & Yes & Yes & $\ldots$ & Yes & Yes & Yes \\
\hline $\mathrm{La}_{7} \mathrm{P}_{3} \mathrm{O}_{18}$ & 0.3 & Yes & No & $\cdots$ & Yes & No & No \\
\hline $\mathrm{LaPO}_{4}$ & 0.5 & Yes & Yes & Yes & Yes & Yes & Yes \\
\hline $\mathrm{La}_{4}\left(\mathrm{P}_{2} \mathrm{O}_{7}\right)_{3}$ & 0.6 & No & No & No & $\ldots$ & Yes & $\ldots$ \\
\hline $\mathrm{La}_{2} \mathrm{P}_{4} \mathrm{O}_{13}$ & 0.667 & Yes & No & No & $\ldots$ & No & $\ldots$ \\
\hline $\mathrm{LaP}_{3} \mathrm{O}_{9}$ & 0.75 & Yes & Yes & Yes & $\ldots$ & Yes & $\ldots$ \\
\hline $\mathrm{LaP}_{5} \mathrm{O}_{14}$ & 0.833 & Yes & Yes & Yes & $\ldots$ & Yes & $\ldots$ \\
\hline
\end{tabular}

\section{$1.3 \mathrm{La}_{4}\left(P_{2} \mathrm{O}_{7}\right)_{3}$}

Kuznetsov and Vasil'eva ${ }^{[35]}$ obtained $\mathrm{La}_{4}\left(\mathrm{P}_{2} \mathrm{O}_{7}\right)_{3}$ by heating amorphous $\mathrm{La}_{4}\left(\mathrm{P}_{2} \mathrm{O}_{7}\right)_{2} \cdot 12 \mathrm{H}_{2} \mathrm{O}$ which was precipitated in aqueous solutions of $\mathrm{La}\left(\mathrm{NO}_{3}\right)_{3}$ and $M_{4} \mathrm{P}_{2} \mathrm{O}_{7}$ $(M=\mathrm{Li}, \mathrm{Na}, \mathrm{K}) .^{[36]}$ On heating, an endothermic effect was observed at $80-180{ }^{\circ} \mathrm{C}$ corresponding to evaporation of the hydration water. Two exothermic effects were observed at $214-262$ and $684-700{ }^{\circ} \mathrm{C}$. They assumed that the amorphous phase starts to crystalize at $260{ }^{\circ} \mathrm{C}$ to form $\alpha-\mathrm{La}_{4}\left(\mathrm{P}_{2} \mathrm{O}_{7}\right)_{3}$ and it changes irreversibly into the hightemperature form, $\beta-\mathrm{La}_{4}\left(\mathrm{P}_{2} \mathrm{O}_{7}\right)_{3}$, at $684{ }^{\circ} \mathrm{C}$. Gao et al. ${ }^{[37]}$ and Zhang et al. ${ }^{[38]}$ also reported that they obtained $\mathrm{La}_{4}\left(\mathrm{P}_{2} \mathrm{O}_{7}\right)_{3}$ by similar methods. Kropiwnicka ${ }^{[39]}$ synthesized $\mathrm{La}_{4}\left(\mathrm{P}_{2} \mathrm{O}_{7}\right)_{3}$ by heating $\mathrm{NH}_{4} \mathrm{LaP}_{4} \mathrm{O}_{12}$ in a closed system to $280{ }^{\circ} \mathrm{C}$ for $5 \mathrm{~h}$, while heating $\mathrm{NH}_{4} \mathrm{LaP}_{4} \mathrm{O}_{12}$ in an open system to $700{ }^{\circ} \mathrm{C}$ led to the formation of $\mathrm{LaP}_{3} \mathrm{O}_{9}$. Shi et al. ${ }^{[2]}$ obtained $\mathrm{La}_{4}\left(\mathrm{P}_{2} \mathrm{O}_{7}\right)_{3}$ by solid state reaction between $\mathrm{La}_{2}\left(\mathrm{CO}_{3}\right)_{3} \cdot 8 \mathrm{H}_{2} \mathrm{O}$ and $\mathrm{NH}_{4} \mathrm{H}_{2} \mathrm{PO}_{4}$.

\section{$1.4 \mathrm{La}_{2} \mathrm{P}_{4} \mathrm{O}_{13}$}

Park and Kreidler ${ }^{[17]}$ obtained $\mathrm{La}_{2} \mathrm{P}_{4} \mathrm{O}_{13}$ by crystallization from glass. They found that it is stable at temperatures up to $755^{\circ} \mathrm{C}$. However, $\mathrm{La}_{2} \mathrm{P}_{4} \mathrm{O}_{13}$ has not been obtained by other methods even at those temperatures. ${ }^{[19,24,34]}$ The same phenomenon was found for the neodymium analogue, $\mathrm{Nd}_{2} \mathrm{P}_{4} \mathrm{O}_{13}$, by Wong and Kreidler: ${ }^{[34]}$ It was formed by crystallization of a glass, but not formed by direct solid-state reaction. They speculated that $\mathrm{Nd}_{2} \mathrm{P}_{4} \mathrm{O}_{13}$ exists in a metastable state.

\section{Experimental}

\subsection{Sample Preparation}

$\mathrm{La}_{2} \mathrm{O}_{3}$ (Nacalai Tesque, mass fraction purity 0.9999 ) and $\mathrm{H}_{3} \mathrm{PO}_{4}$ (Nacalai Tesque, mass fraction purity 0.85) were used to prepare samples. $\mathrm{La}_{2} \mathrm{O}_{3}$ was heated overnight at $800{ }^{\circ} \mathrm{C}$ prior to use to remove absorbed $\mathrm{H}_{2} \mathrm{O}$ and $\mathrm{CO}_{2} \cdot{ }^{[40]}$ $\mathrm{LaPO}_{4}$ and $\mathrm{LaP}_{3} \mathrm{O}_{9}$ were synthesized by precipitation in phosphoric acid solutions. ${ }^{[41]} \mathrm{La}_{2} \mathrm{O}_{3}$ and $\mathrm{H}_{3} \mathrm{PO}_{4}$ were mixed at a $\mathrm{P} / \mathrm{La}$ molar ratio of 15 in a glassy carbon crucible or PFA beaker. The mixture was heated at $190{ }^{\circ} \mathrm{C}$ in the air for several days until complete dissolution took place. Then the solution was kept at $120{ }^{\circ} \mathrm{C}$ in water vapor $(1 \mathrm{~atm})$ for 4 days to precipitate $\mathrm{LaPO}_{4}$, or at $230{ }^{\circ} \mathrm{C}$ in the air for 2 days to precipitate $\mathrm{LaP}_{3} \mathrm{O}_{9}$. The precipitates were separated from the solution, washed well with hot water and dried at $\sim 90{ }^{\circ} \mathrm{C}$. The $\mathrm{LaPO}_{4}$ precipitates were additionally heated at $800{ }^{\circ} \mathrm{C}$ in the air for $100 \mathrm{~h}$ to eliminate residual water and phosphoric acid.

For preparing samples with compositions between $\mathrm{La}_{2} \mathrm{O}_{3}$ and $\mathrm{LaPO}_{4}$ ("L9P1", "L8P2", "L725P275", "L7P3", and "L6P4"), $\mathrm{La}_{2} \mathrm{O}_{3}$ and $\mathrm{LaPO}_{4}$ powders were mixed in the molar ratios listed in Table 2. The mixtures were then ballmilled for 70-100 $\mathrm{h}$ in isopropyl alcohol, dried, and pressed into pellets at $\sim 150 \mathrm{MPa}$. The sample with a composition slightly poorer in $\mathrm{P}_{2} \mathrm{O}_{5}$ than $\mathrm{LaP}_{3} \mathrm{O}_{9}$, "L25P75- $\delta$ ", was prepared from $\mathrm{LaP}_{3} \mathrm{O}_{9}$. The $\mathrm{LaP}_{3} \mathrm{O}_{9}$ precipitate was ground and pressed into a pellet at $\sim 400 \mathrm{MPa}$. The pellet was heated at $1050{ }^{\circ} \mathrm{C}$ for $3 \mathrm{~h}$, to be partially decomposed according to the following reaction: ${ }^{[17,42]}$

$\mathrm{LaP}_{3} \mathrm{O}_{9}(\mathrm{~s}) \rightarrow \mathrm{LaPO}_{4}(\mathrm{~s})+1 / 2 \mathrm{P}_{4} \mathrm{O}_{10}(\mathrm{~g})$

The weight loss due to partial decomposition was $1.4 \mathrm{wt} . \%$, while that of 37.8 wt.\% was expected if complete decomposition took place.

\subsection{Phase Equilibrium Experiments and Sample Characterization}

Phase equilibrium experiments were carried out by hightemperature heat treatments and subsequent phase identification. The sample pellets were placed in alumina crucibles, and heated at a predetermined temperature for typically $100 \mathrm{~h}$ in the air. Then the samples were cooled down in the furnace. The conditions for each heat treatment, e.g., temperature and duration, are provided in the following section. Phase identification was carried out via $\mathrm{x}$-ray powder diffraction (XRD) analysis on PANalytical X'PertPro MPD using $\mathrm{Cu} \mathrm{K} \alpha$ radiation at room temperature. 
Table 2 Compositions of samples

\begin{tabular}{|c|c|c|c|}
\hline Sample & Starting materials & Molar ratio, $\mathbf{P} /(\mathbf{L a}+\mathbf{P})$ & Remarks \\
\hline L9P1 & $\mathrm{La}_{2} \mathrm{O}_{3}$ and $\mathrm{LaPO}_{4}$ & 0.1 & Between $\mathrm{La}_{2} \mathrm{O}_{3}$ and " $\mathrm{La}_{5} \mathrm{PO}_{10}$ " \\
\hline L8P2 & $\mathrm{La}_{2} \mathrm{O}_{3}$ and $\mathrm{LaPO}_{4}$ & 0.2 & Between " $\mathrm{La}_{5} \mathrm{PO}_{10}$ " and $\mathrm{La}_{3} \mathrm{PO}_{7}$ \\
\hline L725P275 & $\mathrm{La}_{2} \mathrm{O}_{3}$ and $\mathrm{LaPO}_{4}$ & 0.275 & Between $\mathrm{La}_{3} \mathrm{PO}_{7}$ and " $\mathrm{La}_{7} \mathrm{P}_{3} \mathrm{O}_{18}$ " \\
\hline L7P3 & $\mathrm{La}_{2} \mathrm{O}_{3}$ and $\mathrm{LaPO}_{4}$ & 0.3 & Composition of " $\mathrm{La}_{7} \mathrm{P}_{3} \mathrm{O}_{18}$ " \\
\hline L6P4 & $\mathrm{La}_{2} \mathrm{O}_{3}$ and $\mathrm{LaPO}_{4}$ & 0.4 & Between " $\mathrm{La}_{7} \mathrm{P}_{3} \mathrm{O}_{18}$ " and $\mathrm{LaPO}_{4}$ \\
\hline $\mathrm{L} 25 \mathrm{P} 75-\delta$ & $\mathrm{LaP}_{3} \mathrm{O}_{9}$ & $0.75-\delta$ & Slightly poorer in $\mathrm{P}_{2} \mathrm{O}_{5}$ than $\mathrm{LaP}_{3} \mathrm{O}_{9}$ \\
\hline
\end{tabular}

Table 3 Phases detected by x-ray diffraction analysis: after single heat treatments of L9P1, L8P2, L725P275, L6P4, and L25P75- $\delta$ samples

Heat treatment

\begin{tabular}{|c|c|c|c|}
\hline \multirow[b]{2}{*}{ Sample } & & \multirow[b]{2}{*}{ Phases present after heat treatments } \\
\hline & Temperature, ${ }^{\circ} \mathrm{C}$ & Time, h & \\
\hline L9P1 & 1300 & 100 & $\mathrm{La}_{2} \mathrm{O}_{3}+\beta-\mathrm{La}_{3} \mathrm{PO}_{7}$ \\
\hline L8P2 & 1300 & 100 & $\mathrm{La}_{2} \mathrm{O}_{3}+\beta-\mathrm{La}_{3} \mathrm{PO}_{7}$ \\
\hline L8P2 & 1000 & 100 & $\mathrm{La}_{2} \mathrm{O}_{3}+\beta-\mathrm{La}_{3} \mathrm{PO}_{7}$ \\
\hline L725P275 & 1300 & 100 & $\beta-\mathrm{La}_{3} \mathrm{PO}_{7}+\mathrm{La}_{7} \mathrm{P}_{3} \mathrm{O}_{18}$ \\
\hline L725P275 & 1000 & 100 & $\beta-\mathrm{La}_{3} \mathrm{PO}_{7}+\mathrm{LaPO}_{4}$ \\
\hline L6P4 & 1300 & 100 & $\mathrm{La}_{7} \mathrm{P}_{3} \mathrm{O}_{18}+\mathrm{LaPO}_{4}$ \\
\hline L6P4 & 1000 & 100 & $\beta-\mathrm{La}_{3} \mathrm{PO}_{7}+\mathrm{LaPO}_{4}$ \\
\hline $\mathrm{L} 25 \mathrm{P} 75-\delta$ & 1050 & 3 & $\mathrm{LaPO}_{4}+\mathrm{LaP}_{3} \mathrm{O}_{9}$ \\
\hline $\mathrm{L} 25 \mathrm{P} 75-\delta$ & 700 & 100 & $\mathrm{LaPO}_{4}+\mathrm{LaP}_{3} \mathrm{O}_{9}$ \\
\hline
\end{tabular}

\section{Results and Discussion}

\section{1 $\mathrm{La}_{2} \mathrm{O}_{3}-\mathrm{LaPO}_{4}$ Subsystem}

3.1.1 Phase Relationships at 1000 and $1300{ }^{\circ} \mathrm{C}$. The $\mathrm{La}_{2} \mathrm{O}_{3}-\mathrm{LaPO}_{4}$ subsystem may contain three intermediate compounds, $\mathrm{La}_{5} \mathrm{PO}_{10}, \mathrm{La}_{3} \mathrm{PO}_{7}$, and $\mathrm{La}_{7} \mathrm{P}_{3} \mathrm{O}_{18}$. The phase relationships in this subsystem were investigated at 1000 and $1300{ }^{\circ} \mathrm{C}$ using samples L9P1, L8P2, L725P275, and L6P4. The samples were heated at each temperature for $100 \mathrm{~h}$. The samples did not show any sign of melting. The detected phases in each sample after each heat treatment are summarized in Table 3. At both temperatures, intermediate phases were formed by reaction between $\mathrm{LaPO}_{4}$ and $\mathrm{La}_{2} \mathrm{O}_{3}$. The coexistence of the initial phases, $\mathrm{La}_{2} \mathrm{O}_{3}$ and $\mathrm{LaPO}_{4}$, was not observed after the heat treatments. At $1000{ }^{\circ} \mathrm{C}, \mathrm{La}_{3} \mathrm{PO}_{7}$ was the only intermediate compound formed in the $\mathrm{La}_{2} \mathrm{O}_{3}$ $\mathrm{LaPO}_{4}$ subsystem. In contrast, at $1300{ }^{\circ} \mathrm{C}, \mathrm{La}_{3} \mathrm{PO}_{7}$ and $\mathrm{La}_{7} \mathrm{P}_{3} \mathrm{O}_{18}$ were formed. $\mathrm{La}_{5} \mathrm{PO}_{10}$ was not detected at either temperature. It should be noted that although $\mathrm{La}(\mathrm{OH})_{3}$ was detected in some samples by XRD, it is treated as $\mathrm{La}_{2} \mathrm{O}_{3}$ in this paper because it should have formed by hydration of $\mathrm{La}_{2} \mathrm{O}_{3}$ during handling at room temperature. As for $\mathrm{La}_{3} \mathrm{PO}_{7}$, Park and Kreidler ${ }^{[17]}$ observed an $\alpha-\beta$ phase transition at $935 \pm 5^{\circ} \mathrm{C}$. The present $\mathrm{x}$-ray diffraction results coincide with the $\beta$-phase pattern given by Park and Kreidler.

3.1.2 Formation and Stability of $\mathrm{La}_{7} \mathrm{P}_{3} \mathrm{O}_{18}$. Since $\mathrm{La}_{7} \mathrm{P}_{3} \mathrm{O}_{18}$ was formed at $1300{ }^{\circ} \mathrm{C}$ while it was not formed at $1000{ }^{\circ} \mathrm{C}$ as described above, the phase evolution behavior at the composition $\mathrm{La}: \mathrm{P}=7: 3$ was investigated in the temperature range $1000-1300{ }^{\circ} \mathrm{C}$ with long-term heat treatments. The L7P3 samples were subjected to two temperature programs consisting of successive heat treatments applied in ascending or descending temperature orders, i.e. heating and cooling processes. X-ray diffraction analysis was carried out at room temperature between each heat treatment.

Table 4 shows the phases detected by $\mathrm{x}$-ray diffraction during the heating and cooling processes. During the heating process, only $\mathrm{La}_{3} \mathrm{PO}_{7}$ and $\mathrm{LaPO}_{4}$ were present both after the heat treatment at $1000{ }^{\circ} \mathrm{C}$ for $1000 \mathrm{~h}$ and after that at $1100{ }^{\circ} \mathrm{C}$ for $200 \mathrm{~h}$. $\mathrm{La}_{7} \mathrm{P}_{3} \mathrm{O}_{18}$ was detected only after the heat treatment at $1200{ }^{\circ} \mathrm{C}$ for $100 \mathrm{~h}$. The sequence of reactions occurred during the heating process is expressed as follows:

$\mathrm{La}_{2} \mathrm{O}_{3}+\mathrm{LaPO}_{4} \rightarrow \mathrm{La}_{3} \mathrm{PO}_{7}\left(<1000{ }^{\circ} \mathrm{C}\right)$,

$2 \mathrm{La}_{3} \mathrm{PO}_{7}+\mathrm{LaPO}_{4} \rightarrow \mathrm{La}_{7} \mathrm{P}_{3} \mathrm{O}_{18}\left(\sim 1200{ }^{\circ} \mathrm{C}\right)$

This indicates that $\mathrm{La}_{7} \mathrm{P}_{3} \mathrm{O}_{18}$ is thermodynamically stable at $\sim 1200{ }^{\circ} \mathrm{C}$ or higher. In the cooling process, $\mathrm{La}_{7} \mathrm{P}_{3} \mathrm{O}_{18}$ was formed by the initial heat treatment at $1300{ }^{\circ} \mathrm{C}$ for $100 \mathrm{~h}$ and it remained unchanged after the heat treatment at $1000{ }^{\circ} \mathrm{C}$ for $900 \mathrm{~h}$. Any sign of decomposition, i.e. the reverse reaction of $\mathrm{Eq} 3$, was not observed. Based on these results, both single phase $\mathrm{La}_{7} \mathrm{P}_{3} \mathrm{O}_{18}$ and the mixture of $\mathrm{La}_{3} \mathrm{PO}_{7} / \mathrm{LaPO}_{4}$ are apparently stable at $1000{ }^{\circ} \mathrm{C}$ for at least $\sim 1000 \mathrm{~h}$. It indicates that the equilibrium state is difficult to attain at $1000{ }^{\circ} \mathrm{C}$ due to kinetic reasons. The similar effect was also observed for the neodymium analogue, $\mathrm{Nd}_{7} \mathrm{P}_{3} \mathrm{O}_{18}{ }^{[20,34]}$ While the formation of $\mathrm{La}_{7} \mathrm{P}_{3} \mathrm{O}_{18}$ and $\mathrm{Nd}_{7} \mathrm{P}_{3} \mathrm{O}_{18}$ by Eq 3 has been observed by several groups, ${ }^{[27,29,31,34]}$ the reverse reaction has never been 
Table 4 Phases detected by $x$-ray diffraction analysis: after successive heat treatments of L7P3 samples

\begin{tabular}{lcccc}
\hline \multirow{2}{*}{ Sample } & Process & \multicolumn{2}{c}{ Heat treatment } & \\
\cline { 3 - 4 } & Temp, ${ }^{\circ} \mathbf{C}$ & Time, $\mathbf{h}$ & $\begin{array}{c}\text { Phases present after } \\
\text { heat treatments }\end{array}$ \\
\hline L7P3 & \multirow{2}{*}{ Heating } & 1000 & 1000 & $\beta-\mathrm{La}_{3} \mathrm{PO}_{7}+\mathrm{LaPO}_{4}$ \\
& & 1100 & 200 & $\beta-\mathrm{La}_{3} \mathrm{PO}_{7}+\mathrm{LaPO}_{4}$ \\
& & 1200 & 100 & $\mathrm{La}_{7} \mathrm{P}_{3} \mathrm{O}_{18}$ \\
\hline L7P3 & \multirow{2}{*}{ Cooling } & 1300 & 100 & $\mathrm{La}_{7} \mathrm{P}_{3} \mathrm{O}_{18}$ \\
& & 1000 & 900 & $\mathrm{La}_{7} \mathrm{P}_{3} \mathrm{O}_{18}$ \\
\hline
\end{tabular}

reported to occur. Therefore, it is reasonable to assume that $\mathrm{La}_{7} \mathrm{P}_{3} \mathrm{O}_{18}$ and $\mathrm{Nd}_{7} \mathrm{P}_{3} \mathrm{O}_{18}$ are thermodynamically stable, but the formation of these compounds from solid phases seems to be kinetically inhibited at low temperatures.

With regard to the $\mathrm{La}_{2} \mathrm{O}_{3}-\mathrm{LaPO}_{4}$ subsystem, it can be concluded that the present results are completely consistent with the phase diagram given by Park and Kreidler. ${ }^{[17]}$ $\mathrm{La}_{5} \mathrm{PO}_{10}$, which appears only in the phase diagrams by Kropiwnicka and Znamierowska, ${ }^{[18,28]}$ was not obtained in this study. As there is little information available on $\mathrm{La}_{5} \mathrm{PO}_{10}$, the reason why it did not form is not clear.

\section{2 $\mathrm{LaPO}_{4}-\mathrm{LaP}_{3} \mathrm{O}_{9}$ Subsystem}

The $\mathrm{LaPO}_{4}-\mathrm{LaP}_{3} \mathrm{O}_{9}$ subsystem may contain two intermediate compounds, $\mathrm{La}_{4}\left(\mathrm{P}_{2} \mathrm{O}_{7}\right)_{3}$ and $\mathrm{La}_{2} \mathrm{P}_{4} \mathrm{O}_{13}$ (decomposes at above $755^{\circ} \mathrm{C}^{[17]}$ ). The phase relationships in this subsystem were examined using the sample L25P75- $\delta$. $\mathrm{L} 25 \mathrm{P} 75-\delta$ was synthesized at $1050{ }^{\circ} \mathrm{C}$ and then heattreated at $700{ }^{\circ} \mathrm{C}$ for $100 \mathrm{~h}$. The weight loss at $700{ }^{\circ} \mathrm{C}$ was negligible (less than $1 \%$ ). The last two rows of Table 3 give the phases present before and after the heat treatment of L25P75- $\delta$ at $700{ }^{\circ} \mathrm{C}$. At both stages, the sample consisted only of $\mathrm{LaPO}_{4}$ and $\mathrm{LaP}_{3} \mathrm{O}_{9}$, and no other phases such as $\mathrm{La}_{4}\left(\mathrm{P}_{2} \mathrm{O}_{7}\right)_{3}$ and $\mathrm{La}_{2} \mathrm{P}_{4} \mathrm{O}_{13}$ were detected. Therefore, $\mathrm{LaPO}_{4}$ and $\mathrm{LaP}_{3} \mathrm{O}_{9}$ are considered in equilibrium at both $1050{ }^{\circ} \mathrm{C}$ (sample preparation temperature) and $700{ }^{\circ} \mathrm{C}$.

A literature survey leads to an idea that $\mathrm{La}_{4}\left(\mathrm{P}_{2} \mathrm{O}_{7}\right)_{3}$ and $\mathrm{La}_{2} \mathrm{P}_{4} \mathrm{O}_{13}$ are metastable phases. As described in the Introduction, Kuznetsov and Vasil'eva ${ }^{[35]}$ proposed an $\alpha-\beta$ phase transition at $684{ }^{\circ} \mathrm{C}$ for $\mathrm{La}_{4}\left(\mathrm{P}_{2} \mathrm{O}_{7}\right)_{3}$. However, the $\mathrm{x}$-ray diffraction pattern for the high-temperature phase ( $\beta$-phase) given by them indicates that it consists mainly of $\mathrm{LaPO}_{4}$. Therefore, it is likely that $\mathrm{La}_{4}\left(\mathrm{P}_{2} \mathrm{O}_{7}\right)_{3}$ decomposes to $\mathrm{LaPO}_{4}$ and probably $\mathrm{LaP}_{3} \mathrm{O}_{9}$ at above $684{ }^{\circ} \mathrm{C}$, instead of undergoing a structural phase transition. In addition, since the thermal effect at $684{ }^{\circ} \mathrm{C}$ on heating is exothermic and irreversible, ${ }^{[35]}$ the low-temperature form of $\mathrm{La}_{4}\left(\mathrm{P}_{2} \mathrm{O}_{7}\right)_{3}$ is considered to be in a non-equilibrium (probably metastable) state. According to several reports, ${ }^{[21,35,38,39]}$ it is supposed that $\mathrm{La}_{4}\left(\mathrm{P}_{2} \mathrm{O}_{7}\right)_{3}$ can form through the dehydration of precursors on heating.

As for $\mathrm{La}_{2} \mathrm{P}_{4} \mathrm{O}_{13}$, it has been obtained only by crystallization from glass, and it was reported to decompose into $\mathrm{LaPO}_{4}$ and $\mathrm{LaP}_{3} \mathrm{O}_{9}$ at above $755{ }^{\circ} \mathrm{C} \cdot{ }^{[17]}$ Wong and Kreidler remarked that $\mathrm{La}_{2} \mathrm{P}_{4} \mathrm{O}_{13}$ and $\mathrm{Nd}_{2} \mathrm{P}_{4} \mathrm{O}_{13}$ could not be formed by solid state reaction, and they speculated that $\mathrm{Nd}_{2} \mathrm{P}_{4} \mathrm{O}_{13}$

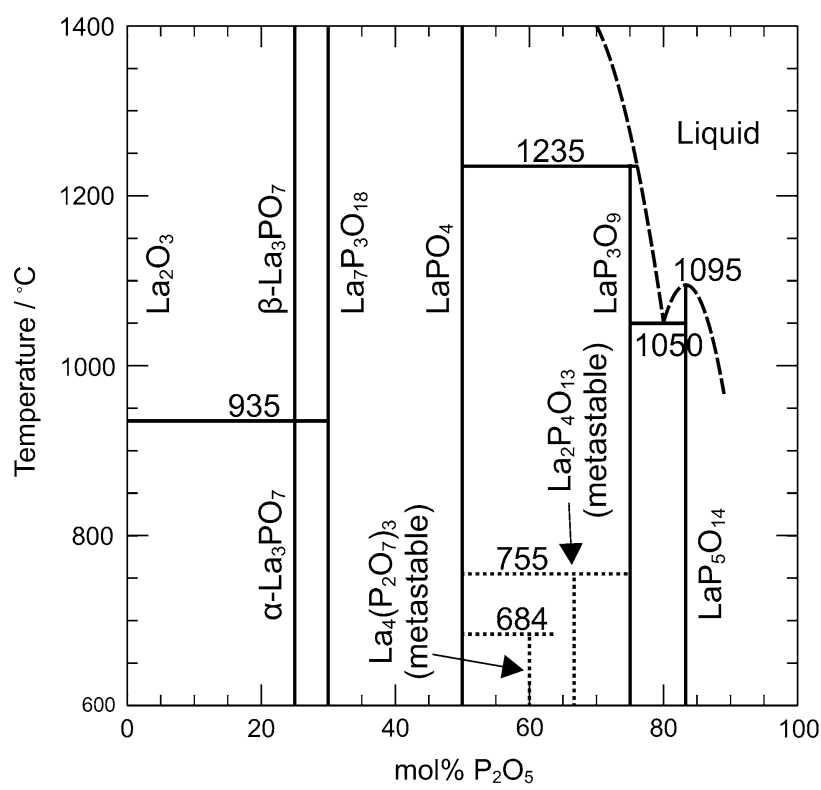

Fig. 1 Phase diagram of the $\mathrm{La}_{2} \mathrm{O}_{3}-\mathrm{P}_{2} \mathrm{O}_{5}$ system adapted from Park and Kreidler. ${ }^{17]}$ Slight modifications were made to the original diagram so that $\mathrm{La}_{2} \mathrm{P}_{4} \mathrm{O}_{13}$ is now shown as a metastable phase and $\mathrm{La}_{4}\left(\mathrm{P}_{2} \mathrm{O}_{7}\right)_{3}$ which was not included in the original diagram is now included as a metastable phase

exists in a metastable state. ${ }^{[34]}$ In general, it has been shown that intermediate metastable phases tend to form during the crystallization of largely undercooled amorphous phases. ${ }^{\text {[3, }}{ }^{44]}$

Finally, the above idea is also consistent with the results of solution growth of lanthanum phosphates in phosphoric acid solutions. ${ }^{[19,41]}$ It has been shown that anhydrous $\mathrm{LaPO}_{4}$ and $\mathrm{LaP}_{3} \mathrm{O}_{9}$ can directly be precipitated in homogeneous phosphoric acid solutions at $100-400{ }^{\circ} \mathrm{C}$. If $\mathrm{La}_{2} \mathrm{P}_{4} \mathrm{O}_{13}$ and $\mathrm{La}_{4}\left(\mathrm{P}_{2} \mathrm{O}_{7}\right)_{3}$ are also thermodynamically stable phases, equilibria between each phosphate and phosphoric acid solution are expected to exist in this temperature range, based on previously reported phase relations in the $\mathrm{La}_{2} \mathrm{O}_{3}$ $\mathrm{P}_{2} \mathrm{O}_{5}-\mathrm{H}_{2} \mathrm{O}$ system. ${ }^{[19,41]}$ However, the precipitation of $\mathrm{La}_{4}\left(\mathrm{P}_{2} \mathrm{O}_{7}\right)_{3}$ and $\mathrm{La}_{2} \mathrm{P}_{4} \mathrm{O}_{13}$ has never been observed at any temperature between 100 and $400{ }^{\circ} \mathrm{C}$, in spite that these experiments were carried out over relatively long periods of time (several days) to allow the equilibrium states to be reached. Thus we currently speculate that $\mathrm{La}_{4}\left(\mathrm{P}_{2} \mathrm{O}_{7}\right)_{3}$ and $\mathrm{La}_{2} \mathrm{P}_{4} \mathrm{O}_{13}$ are metastable phases, although thermodynamic evidence is still required.

\subsection{Phase Diagram of the $\mathrm{La}_{2} \mathrm{O}_{3}-\mathrm{P}_{2} \mathrm{O}_{5}$ System}

Figure 1 presents the verified phase diagram of the $\mathrm{La}_{2} \mathrm{O}_{3}-\mathrm{P}_{2} \mathrm{O}_{5}$ system which is mainly adopted from Ref 17 and slightly modified to reflect the discussion above. The present results confirm the existence of $\mathrm{La}_{3} \mathrm{PO}_{7}, \mathrm{La}_{7} \mathrm{P}_{3} \mathrm{O}_{18}$, $\mathrm{LaPO}_{4}$, and $\mathrm{LaP}_{3} \mathrm{O}_{9}$ as thermodynamically stable phases in the $\mathrm{La}_{2} \mathrm{O}_{3}-\mathrm{P}_{2} \mathrm{O}_{5}$ system. The existence of $\mathrm{LaP}_{5} \mathrm{O}_{14}$ has also been well established in previous studies. Although $\mathrm{La}_{4}\left(\mathrm{P}_{2} \mathrm{O}_{7}\right)_{3}$ and $\mathrm{La}_{2} \mathrm{P}_{4} \mathrm{O}_{13}$ can also form in this system under certain conditions, it is likely that these compounds are metastable. Phase transformation and melting temperatures 
of $\mathrm{La}_{3} \mathrm{PO}_{7}, \mathrm{LaP}_{3} \mathrm{O}_{9}$, and $\mathrm{LaP}_{5} \mathrm{O}_{14}$ shown in Fig. 1 are taken from Ref 17, as they were not investigated in this study. It should be noted that $\mathrm{LaP}_{3} \mathrm{O}_{9}$ and $\mathrm{LaP}_{5} \mathrm{O}_{14}$ gradually decompose under atmospheric conditions with the loss of $\mathrm{P}_{4} \mathrm{O}_{10}$ even below their melting temperatures as reported in Ref $17,42$.

\section{Conclusions}

The phase equilibria between the solid phases in the $\mathrm{La}_{2} \mathrm{O}_{3}-\mathrm{P}_{2} \mathrm{O}_{5}$ system were reinvestigated with solid state reaction method. The existence of $\mathrm{La}_{3} \mathrm{PO}_{7}, \mathrm{La}_{7} \mathrm{P}_{3} \mathrm{O}_{18}$, $\mathrm{LaPO}_{4}$, and $\mathrm{LaP}_{3} \mathrm{O}_{9}$ was confirmed. $\mathrm{La}_{7} \mathrm{P}_{3} \mathrm{O}_{18}$ can form only at $\sim 1200{ }^{\circ} \mathrm{C}$ or higher possibly due to kinetic reasons, but it is stable at lower temperatures. On the other hand, three intermediate compounds proposed to exist, $\mathrm{La}_{5} \mathrm{PO}_{10}$, $\mathrm{La}_{4}\left(\mathrm{P}_{2} \mathrm{O}_{7}\right)_{3}$, and $\mathrm{La}_{2} \mathrm{P}_{4} \mathrm{O}_{13}$ were not obtained in this study. Based on the literature, $\mathrm{La}_{4}\left(\mathrm{P}_{2} \mathrm{O}_{7}\right)_{3}$ and $\mathrm{La}_{2} \mathrm{P}_{4} \mathrm{O}_{13}$ are considered to be metastable phases, although thermodynamic evidence is still required.

\section{Acknowledgments}

This work was financially supported by MEXT Elements Science and Technology Project and a Grant-in-Aid for JSPS Fellows. The authors would like to thank A. Kuramitsu for her technical assistance.

\section{References}

1. T. Norby and N. Christiansen, Proton Conduction in Ca- and Sr-Substituted $\mathrm{LaPO}_{4}$, Solid State Ion., 1995, 77, p 240-243

2. K. Amezawa, Y. Tomii, and N. Yamamoto, High-Temperature Protonic Conduction in $\mathrm{La}_{7} \mathrm{P}_{3} \mathrm{O}_{18}$, Solid State Ion., 2004, 175, p 569-573

3. K. Amezawa, Y. Kitajima, Y. Tomii, and N. Yamamoto, HighTemperature Protonic Conduction in $\mathrm{LaP}_{3} \mathrm{O}_{9}$, Electrochem. Solid-State Lett., 2004, 7(12), p A511-A514

4. I. Hammas, K. Horchani-Naifer, and M. Férid, Conduction Properties of Condensed Lanthanum Phosphates: $\mathrm{La}\left(\mathrm{PO}_{3}\right)_{3}$ and $\mathrm{LaP}_{5} \mathrm{O}_{14}, J$. Rare Earths, 2010, 28(3), p 321-328

5. R.C. Ropp, Phosphors Based on Rare Earth Phosphates, J. Electrochem. Soc., 1968, 115(8), p 841-845

6. T.C. Damen, H.P. Weber, and B.C. Tofield, NdLa Pentaphosphate Laser Performance, Appl. Phys. Lett., 1973, 23(9), p 519-520

7. E.B. Stucchi, A.M. de Castro, M.A. Couto Dos Santos, and P. Melnikov, Synthesis, Characterization and Spectroscopy of the Europium Doped Lanthanum Trimetaphosphate, J. Alloys Compd., 1988, 275-277, p 86-88

8. S. Lu and J. Zhang, Study on UV Excitation Properties of $\mathrm{Eu}^{3+}$-Doped Rare-Earth Phosphates, J. Lumin., 2007, 122-123, p 500-502

9. K. Gunjigake, M. Hasegawa, H. Oizumi, and Y. Ogata, United States Patent 4,033,790, 5 July 1977

10. G.R. Pickrell and J.E. Rapp, United States Patent 5,350,460, 27 Sep 1994

11. M. Tao, H. Xiao, T. Sun, and W. Guo, Preparation of $\mathrm{LaP}_{5} \mathrm{O}_{14}$ Powder by Sol-Gel Method, J. Chin. Ceram. Soc., 2010, 38(8), p 1553-1557
12. P.E.D. Morgan and D.B. Marshall, Functional Interfaces for Oxide/Oxide Composites, Mater. Sci. Eng., 1993, A162, p 15-25

13. S.V. Komarov, S.E. Romankov, S.H. Son, N. Hayashi, S.D. Kaloshkin, S. Ueno, and E. Kasai, Production of $\mathrm{LaPO}_{4}$ Coatings Using a Novel Ultrasonically-Assisted Plating Technique, Surf. Coat. Technol., 2008, 202, p 5180-5184

14. G.J. McCarthy, W.B. White, and D.E. Pfoertsch, Synthesis of Nuclear Waste Monazites, Ideal Actinide Hosts for Geologic Disposal, Mater. Res. Bull., 1978, 13, p 1239-1245

15. A. Meldrum, L.A. Boatner, and R.C. Ewing, Displacive Radiation Effects in the Monazite- and Zircon-Structure Orthophosphates, Phys. Rev. B, 1997, 56(21), p 1380513814

16. B. Glorieux, M. Matecki, F. Fayon, J.P. Coutures, S. Palau, A. Douy, and G. Peraudeau, Study of Lanthanum Orthophosphates Polymorphism, in View of Actinide Conditioning, J. Nucl. Mater, 2004, 326, p 156-162

17. H.D. Park and E.R. Kreidler, Phase Equilibria in the System $\mathrm{La}_{2} \mathrm{O}_{3}-\mathrm{P}_{2} \mathrm{O}_{5}, J$. Am. Ceram. Soc., 1984, 67(1), p 23-26

18. J. Kropiwnicka and T. Znamierowska, Phase Equilibria in the System $\mathrm{La}_{2} \mathrm{O}_{3}-\mathrm{Na}_{2} \mathrm{O}-\mathrm{P}_{2} \mathrm{O}_{5}$. Part I. Side System $\mathrm{La}_{2} \mathrm{O}_{3}-\mathrm{P}_{2} \mathrm{O}_{5}$, Pol. J. Chem., 1988, 62, p 587-594

19. N.N. Chudinova, L.P. Shklover, and G.M. Balagina, Reactions of Lanthanum Oxide with Phosphoric Acids at $100-500{ }^{\circ} \mathrm{C}$, Inorg. Mater., 1975, 11, p 590-593

20. E.G. Tselebrovskaya, B.F. Dzhurinskii, A.V. Lavrov, and A. Durif, Interaction in the Systems $\mathrm{Ln}_{2} \mathrm{O}_{3}-\mathrm{GeO}_{2}-\mathrm{P}_{2} \mathrm{O}_{5}$, Russ. J. Inorg. Chem., 1994, 39(3), p 473-474

21. Y. Shi, J. Liang, Y. Guo, J. Yang, W. Zhuang, and R. Guanghui, Phase Relations in the System $\mathrm{La}_{2} \mathrm{O}_{3}-\mathrm{B}_{2} \mathrm{O}_{3}-\mathrm{P}_{2} \mathrm{O}_{5}$, J. Alloys Compd., 1996, 242, p 118-121

22. R. El Ouenzerf, C. Goutaudier, G. Panczer, B. Moine, M.T. Cohen-Adad, M. Trabelsi-Ayedi, and N. Kbir-Ariguib, Investigation of the $\mathrm{CaO}-\mathrm{La}_{2} \mathrm{O}_{3}-\mathrm{SiO}_{2}-\mathrm{P}_{2} \mathrm{O}_{5}$ Quaternary Diagram. Synthesis, Existence Domain, and Characterization of Apatitic Phosphosilicates, Solid State Ion., 2003, 156, p 209-222

23. K. Toyoura, N. Hatada, Y. Nose, T. Uda, and I. Tanaka, FirstPrinciples Thermodynamics of $\mathrm{La}_{2} \mathrm{O}_{3}-\mathrm{P}_{2} \mathrm{O}_{5}$ Pseudobinary System, Phys. Rev. B, 2011, 84(18), p 184301

24. M. Tsuhako, S. Ikeuchi, T. Matsuo, I. Motooka, and M. Kobayashi, Conditions of the Formation of Rare Earth Phosphates and the Colors of Their Powders, Bull. Chem. Soc. Jpn., 1979, 52(4), p 1034-1040

25. R.D. Plättner, W.W. Krühler, W.K. Zwicker, T. Kovats, and S.R. Chinn, The Growth of Large, Laser Quality $\mathrm{Nd}_{x} \mathrm{RE}_{1-x-}$ $\mathrm{P}_{5} \mathrm{O}_{14}$, J. Cryst. Growth, 1980, 49, p 274-290

26. M. Yoshimura, K. Fujii, and S. Somiya, Phase Equilibria in the System $\mathrm{Nd}_{2} \mathrm{O}_{3}-\mathrm{P}_{2} \mathrm{O}_{5}-\mathrm{H}_{2} \mathrm{O}$ and Growth of $\mathrm{NdP}_{5} \mathrm{O}_{14}$ Single Crystals under Hydrothermal Conditions, J. Cryst. Growth, 1985, 71, p 333-339

27. E.G. Tselebrovskaya, B.F. Dzhurinskii, G.V. Lysanova, and M.G. Komava, Intermediate and Metastable Phases in the Synthesis of Various Lanthanide Phosphates, Russ. J. Inorg. Chem., 1991, 36(10), p 1387-1389

28. J. Kropiwnicka, Phase Equilibria in the System $\mathrm{La}_{2} \mathrm{O}_{3}-\mathrm{Na}_{2} \mathrm{O}-$ $\mathrm{P}_{2} \mathrm{O}_{5}$ The Partial System $\mathrm{La}_{2} \mathrm{O}_{3}-\mathrm{Na}_{4} \mathrm{La}_{2} \mathrm{P}_{4} \mathrm{O}_{15}-\mathrm{LaPO}_{4}$, J. Therm. Anal., 1990, 36, p 979-990

29. J.J. Serra, J. Coutures, and A. Rouanet, Traitements Thermiques des Orthophosphates de Lanthanides $\mathrm{LnPO}_{4}$ et Formation de Nouveaux Composés (Oxyphosphates), High Temp. High Press., 1976, 8, p 337-341

30. J.J. Serra, J. Coutures, A. Rouanet, H. Dexpert, and G. Garon, Etude des Familles d'Oxyphosphates de Lanthanides (Ln/ $\mathrm{P}>1$ ): Synthèse, Caractérisation et Stabilité Thermique, Rev. Int. Hautes Temp. Refract., 1978, 15, p 287-313 
31. A. Rouanet, J.J. Serra, K. Allaf, and V.P. Orlovskii, Rare Earth Orthophosphates at High Temperatures, Inorg. Mater., 1981, 17, p 76-81

32. E. Boakye, R.S. Hay, and M.D. Petry, Continuous Coating of Oxide Fiber Tows Using Liquid Precursors: Monazite Coatings on Nextel 720, J. Am. Ceram. Soc., 1999, 82(9), p 2321-2331

33. J.R. Mawdsley and J.W. Halloran, The Effect of Residual Carbon on the Phase Stability of $\mathrm{LaPO}_{4}$ at High Temperatures, J. Eur. Ceram. Soc., 2001, 21, p 751-757

34. M.-S. Wong and E.R. Kreidler, Phase Equilibria in the System $\mathrm{Nd}_{2} \mathrm{O}_{3}-\mathrm{P}_{2} \mathrm{O}_{5}$, J. Am. Ceram. Soc., 1987, 70(6), p 396-399

35. V.G. Kuznetsov and V.P. Vasil'eva, Thermographic and X-ray Studies of Lanthanum Pyrophosphates, Inorg. Mater., 1967, 3(2), p 316-321

36. I.V. Tananaev and V.P. Vasil'eva, Lanthanum Pyrophosphates, Russ. J. Inorg. Chem., 1964, 9(9), p 1141-1144

37. X. Gao, G. Hong, W. Wang, H. Cui, and Y. Li, Preparation and Spectroscopic Properties of $\mathrm{La}_{4}\left(\mathrm{P}_{2} \mathrm{O}_{7}\right)_{3}$ : $\mathrm{Ce}, \mathrm{Gd}, \mathrm{Tb}$ Phosphors, Chin. J. Lumin., 1993, 14(1), p 25-31
38. Z. Zhang, J. Li, and X. Yang, Vapor Phase Beckmann Rearrangement of Cyclohexanone Oxime over Rare Earth Pyrophosphates, Catal. Lett., 2007, 118, p 300-305

39. J. Kropiwnicka, Phase Equilibrium in the System $\mathrm{LaP}_{3} \mathrm{O}_{9^{-}}$ $\mathrm{NaPO}_{3}-\mathrm{P}_{2} \mathrm{O}_{5}$ : The New Compounds $\mathrm{NH}_{4} \mathrm{LaP}_{4} \mathrm{O}_{12}$ and $\mathrm{La}_{4}\left(\mathrm{P}_{2} \mathrm{O}_{7}\right)_{3}$, J. Therm. Anal., 1995, 44, p 725-731

40. S. Bernal, J.A. Díaz, R. García, and J.M. Rodríguez-Izquierdo, Study of Some Aspects of the Reactivity of $\mathrm{La}_{2} \mathrm{O}_{3}$ with $\mathrm{CO}_{2}$ and $\mathrm{H}_{2} \mathrm{O}$, J. Mater. Sci., 1985, 20, p 537-541

41. N. Hatada, Y. Nose, A. Kuramitsu, and T. Uda, Precipitation Behavior of Highly Sr-Doped $\mathrm{LaPO}_{4}$ in Phosphoric Acid Solutions, J. Mater. Chem., 2011, 21, p 8781-8786

42. O.A. Serra and E. Giesbrecht, Lanthanum, Cerium and Praseodymium Trimetaphosphates, J. Inorg. Nucl. Chem., 1968, 30, p 793-799

43. K.N. Ishihara, M. Maeda, and P.H. Shingu, The Nucleation of Metastable Phases from Undercooled Liquids, Acta Metall., 1985, 33(12), p 2113-2117

44. S.-Y. Chung, Y.-M. Kim, J.-G. Kim, and Y.-J. Kim, Multiphase Transformation and Ostwald's Rule of Stages During Crystallization of a Metal Phosphate, Nat. Phys., 2009, 5, p 68-73 